\title{
Psychological Mechanism Explaining the Effect of HR Practices Towards Employee Performance (A Study in Public Higher Education)
}

\section{S. Martono, Nury Ariani Wulansari, Vini Wiratno Putri, and Moh Khoiruddin}

Department of Management, Faculty of Economic, Universitas Negeri Semarang, Semarang, Indonesia

\section{Abstract}

Many empirical studies have used human resource practices and managerial practices as a predictor of service climate as an indicator of employee performance. However, research on the psychological mechanism that explains how up-to-date HR practices affect the high performance of employees is not yet widely explored, especially in

Corresponding Author: Vini Wiratno Putri viniwp@mail.unnes.ac.id

Received: 7 August 2018 Accepted: 15 September 2018 Published: 22 October 2018

Publishing services provided by Knowledge

(c) S. Martono et al. This article is distributed under the terms of the Creative Commons

Attribution License, which permits unrestricted use and redistribution provided that the original author and source are credited.

Selection and Peer-review under the responsibility of the ICE-BEES 2018 Conference Committee. the context of enhancing the quality of higher education management. The reason for selection of the object is the rarity of HR practices implementation studies in the context of higher education. The theory and research of HR practices are only a one-sided study on the side of corporate business interests. The purpose of this study is to examine the influence of two roles of mediation variables (job embeddedness and trust in the leader) on the performance of employees. The sample of this research is 250 employees of public higher education in Central Java. The data are processed using Warp PLS version 6. The results show partial support for the role of mediation variables (job embeddedness and trust in the leader) on employee performance. In other words, to achieve the employees superior performance, is not only come from the implementation of HR practices, but also the management should pay attention to what extent employees have embeddedness to their organization and trust in the leadership. Further research suggestion is to explore deeper other variables that can explain the psychological mechanisms of HM practices to improve employee performance.

Keywords: HR Practice, job embeddedness, trust, Employee Performance. 


\section{Introduction}

The main process undertaken in the MSDM mechanism includes a broad managerial spectrum ranging from Human Resources Planning to termination. Many empirical studies have used human resource practices and managerial practices as predictors of service climate (Schneider et al 1998). Such a climate will reinforce employees' perceptions of how well the existing practices and procedures facilitate excellent service delivery to customers. In addition, it will also reinforce the perception of the quality of the service expected by the company, as well as support and reward from the management for employees for their performance. In our study, instead of using conventional human resource practices such as recruitment, training, performance appraisals, compensation, etc., we apply HR practices which are perceived by the employees as a source of organization that facilitates their work.

The practice of human resources proved to have a positive impact towards work outcome. Research conducted by Kehoe and Wright (2010) shows that HR practices contribute positively to employee performance. This is in line with Hassan (2016) demonstrating that HR practices such as Compensation, Career Planning, Performance Appraisal, Training, and Employee Involvement play an important role in improving the performance of employee tasks.

Several other studies that examining the role of HR practices on performance such as Mahadevan and Mohamed (2014), Munjuri (2011), Qudah and Qudah (2014), Sattar et al (2015) suggest that it is important to keep on improving HR practices to improve employee performance in an organization. In addition to influencing performance, HR practices also seem to have positive psychological effect on employees. Research conducted by Tzafrir et al (2004), Rahman et al (2013) found that good HR practices can create employee trust in their organization and superiors. It is therefore important for organizations to keep on improving HR practices to create a high level of trust. Several other studies that examine HR practices show that HR practices within an organization are also capable of increasing employee job embeddedness. Bambacas and Kulik (2013), Ghosh and Gurunathan (2015) show that good HR practices can create employee embeddedness. The better HR practice applied by the organization, the job embeddedness will also increase.

Some of the above explanations show that the employee positive psychology is greatly influenced by the existence of good HR practices. On the other hand, the positive psychology can also directly affect the performance. Research conducted by 
Lee et al (2004), Ozcelik and Genkci (2014) show that employee job embeddedness will be able to boost their performance.

Research conducted by Brown et al (2015), Akili and Cingoz (2015), Ahmed et al (2016), show that employee trust in their organization and superiors will be able to improve employee performance. The higher the employee trust, the higher they will be in performing.

This study was conducted with several important reasons. First, although there have been many studies that examine the effect of HR practices on work outcome and positive psychology, those studies are conducted separately. Therefore, it is necessary to do research that build the model comprehensively, with the aim of getting a clearer picture of mechanism. Some studies show that the process for achieving performance results is not simple, but through several processes $[49,54]$. That is, it takes explanation of the mediating variables in seeing the effect of HR practices on employee performance. Third, studies that examine HR practices and their impact on work outcome in the realm of Higher Education are scarcely studied. Although there are several studies such as Jouda et al (2016), Nadarajah et al (2012) that examine HR practices in Higher Education, their research has not yet considered the possibility of mediating variable between HR Practices and employee performance. Our study, referring to the research conducted by Fatima et al (2015) which proposes that the influence of HR practices on employee performance in Higher Education through mediating variables such as job embeddedness and trust, is necessary to be done in different countries and universities to produce generalized results.

\section{HR Practice}

Hasibuan (2011) defines human resource management as the science and art of managing relationships and the role of manpower in order to effectively and efficiently help the realization of corporate, employee, and community goals. Ardana (2012) defines human resource management as a process of utilizing human resources effectively and efficiently through the activities of planning, mobilizing, and controlling all values that become human strength to achieve the goal. Schneider and Bowen (1985) found that employee perceptions of MSDM practices were significantly related to customer perception of service quality. When employees feel that they are well treated by the existing MSDM practices, they will be able to devote their energy and resources to serve customers effectively. A study by Schneider and Bowen (1985) on organizational 
practice in branch offices found that the relationship between MSDM practice and strategic outcomes was the strongest in service organizations. MSDM practices can increase the "value" of employees in an organization. Selection practice for instance, has an important role in getting qualified workers who meet the required qualifications of the company. For that purpose, during the selection process, the company must seek to find and attract qualified employees with attitudes and behaviors that support the values and achievement of the organizational goals.

The next challenge is to maintain its existence in long term. Training and development are also critical for the achievement of organizational performance and competitive advantage of the company [18]. Training is also a good practice in overcoming factors that reduce job satisfaction and employee performance. In order to achieve the effectiveness of training, the training program must be fit with the work process and company strategy. Post-training should also ensure a transfer of training that supports the employee learning process. Furthermore, there should be a consideration of rewards for learning efforts by employees that support performance improvement [28]. This is supported by many studies which find that incentives affect organizational performance.

The general purpose of providing incentives is to change behavior, improve positive attitudes and motivate employees to contribute to the growth of the company. A number of studies suggest that HR systems that support team work activities are critical practices for organizational innovation and competitiveness (Lau \& Ngo, 2004). While team activity encourages cooperation and communication among employees, at the same time it supports the creation of an appropriate work culture. Then, feedback on their performance becomes the practice that supervisors need directly in improving the effectiveness of their subordinates' work. Sharing information about the employee individual performance in the practice is a means of enhancing communication between the two parties, thereby it will effectively lead to the openness of organizational communication. All HR management practices that have been described can increase employee trust in the company. One over the other practices supports each other and strengthens the achievement of organizational performance (Zerbe, Dobni, \& Harel, 1998). It cannot be denied that the practice of human resource management can assist the company in improving the company progress and can even assist the company resilience in the business activities undertaken. 


\section{Trust}

The definition of trust according to Mayer, et al (1995) is the overall willingness of a person who is vulnerable to the actions of others (trustee) with the expectation that the party will do certain actions that are important to the trustor. Trust relates to what the organization considers to be true and not, describes the organization's moral characteristics or organizational code of ethics [1].

According to Robbins and Judge (2008), trust is a hope and a positive expectation that others will not go through words, actions, and policies acting opportunistically. Meanwhile, according to Johnson (in [32]) trust is the foundation in establishing and maintaining intrapersonal relationships. With good intrapersonal relationships, it will certainly be a great opportunity in establishing embeddedness and social support between employees to company organization. Trust occurs when one is convinced of the reliability and integrity of a trusted person (Morgan \& Hunt, 1994). Confidence in the party with reliability and integrity will give trust value to the party so that someone can give confidence to something. Altuntas and Baykal (2010) also defines Organizational Trust as a feeling of confidence and commitment without any perception of fear and doubt, in which people believe that they will get support and can work with others in solving a problem without any underlying motives and negative thoughts. Meanwhile, according to Shockly-Zalabak, et al (2000), organizational trust is the willingness of the organization, based on the culture and behavior of communicating in relationships and transactions, to be vulnerable towards individuals, groups, or other organizations on the basis of confidence that they are competent, open and honest, reliable, and identified with purpose, norm, and value.

\section{Job Embeddedness}

The concept of job embeddedness was firstly raised and often used to be a reference by some researchers is the theory of Mitchel. Job embeddedness in an organization can be seen from different perspectives by one organization to another. Similarly, the meaning of job embeddedness itself, the meaning of job embeddedness is also interpreted by organizations differently. Job Embeddedness is defined as one of the networks that encourage individuals to stay in the organization, where the network 
is divided into the organization itself and the community within it [45]. Job embeddedness is a term to represent the reasons that keep employees staying at work and organization [29].

Mitchell, et al (2001) revealed that the Job Embeddedness concept describes how an employee is tied to work and the organization in which he works because of the influence of aspects that come from work (on-the-job) and from outside of the work (off-job). Job embeddedness can also be defined as factors that influence a person's decision to survive or leave their work and organization [12].

Felps, et al (2009) describes the relationship of how well people feel fit to work and organization, such as the relationship between people in work and out of work and what they will lose when they leave their office or organization. Kismono (2011) argues that employees who have Job Embeddedness in their work will feel more attached to colleagues, works and organizations and can express their attachment by maintaining membership of the organization where they work. Individuals who feel a strong bond (embedded) between themselves and their work and organization tend to have a positive behavior in achieving organizational goals than individuals who do not feel a bond between themselves and the organization [24].

Conceptually, the definition of job embeddedness is a person's general attachment to his work [45]. Job embeddedness theory focuses on keeping employees within the organization, rather than keeping them to leave other organizations [38]. Job embeddedness is assumed that the more connections the employee has and those connections fit him well, it will be more likely that the employee will stay in the company or the job.

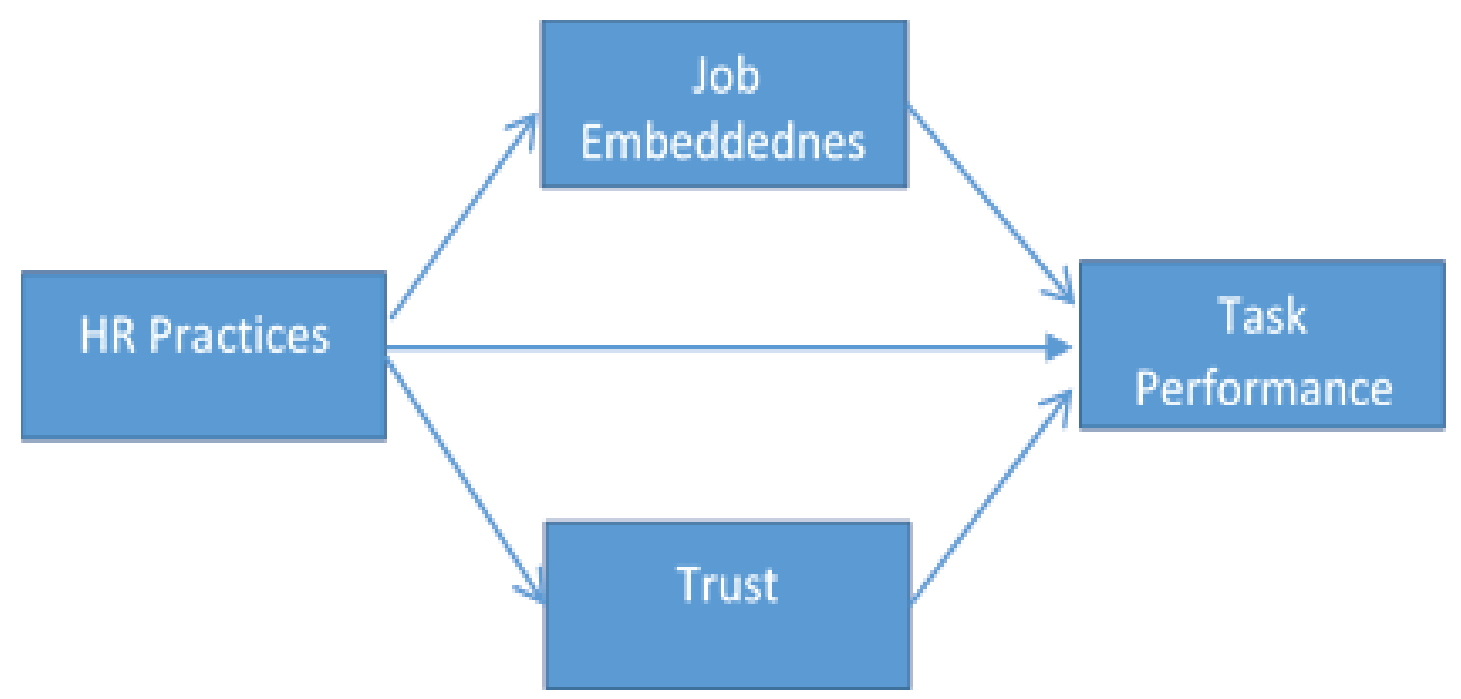

Figure 1: Model of the Study. 
Based on this framework, then the hypotheses are formulated as follows:

- Hypothesis 1: HR Practices have a positive effect on employee performance.

- Hypothesis 2: HR Practices have a positive effect on employee Job Embeddedness.

- Hypothesis 3: HR Practices have a positive effect on employee trust.

- Hypothesis 4: Job embeddedness has a positive effect on employee performance.

- Hypothesis 5: Trust has a positive effect on employee performance.

- Hypothesis 6: Job embeddedness mediates the relationship between Human Resource Practice and Performance Task.

- Hypothesis 7: Trust mediates the relationship between Human Resource Practice and Performance Task.

\section{Research Method}

\subsection{Research design and population}

This research is a causal study since it identifies the cause and effect relationship between different variables. In this primary data-based cross-sectional survey, the data were collected through questionnaires distribution to 250 respondents in UNNES. Research respondents are lecturers and educational staff drawn from all faculties in UNNES. A purposive non-probability sampling technique was used for sampling. In this sampling technique, the sample is limited to a particular type of person who has the information required or in accordance with the criteria set by the researcher (Sekaran \& Bougie, 2010).

Analysis of structural equation modeling (SEM) with WarpPLS program is used to test the hypotheses. This statistical analysis tool is chosen because it has several advantages. First, SEM-PLS is suitable for research models that use latent variables and have calculated the measurement error. Second, SEM analysis can simultaneously test multiple dependences as in this research model. Third, component-based SEM (PLS) can estimate a fairly complex model with a small sample size.

\section{Result and Discussion}




\subsection{Instrument test (validity test and reliability test)}

Two kinds of validity were used in this study; convergent validity and discriminant validity. The explanation of the convergence validity and discriminant validity is as follows:

Convergent validity is measured by using factor loading for the reflective indicator model or component loading for a formative indicator model. If the factor loading $\geq$ 0.30 or the factor loading and component loading of the indicator are significant, the corresponding indicator meets the convergent validity. Based on calculations using WarpPLS 6.0, the result indicates that all such statements are stated to meet the convergent validity since the factor loading $\geq 0.30$ so that the statement items are used in this study. Discriminant validity questionnaire can be seen from the comparison of AVE (Average Variance Extracted) root value with correlation coefficient. If AVE root is greater than correlation coefficient with other variables, then questionnaire is said to be valid discriminant.

TABLE 1: AVE Root and Correlation Coefficient.

\begin{tabular}{l|c|c|c|c|} 
& PSDM & JE & Trust & KP \\
\hline PSDM & $\mathbf{0 . 7 3 1}$ & 0.465 & 0.610 & 0.558 \\
\hline JE & 0.465 & $\mathbf{0 . 7 9 0}$ & 0.490 & 0.573 \\
\hline Trust & 0.610 & 0.490 & $\mathbf{0 . 7 6 1}$ & 0.606 \\
\hline KP & 0.558 & 0.573 & 0.606 & $\mathbf{0 . 6 6 3}$ \\
\hline \multicolumn{2}{l}{ Source: Processed Primary Data (2018) } \\
\end{tabular}

Based on Table 3, the results of the AVE root test and the Correlation Coefficient show that all statement items are greater than the correlation of the relevant variables, so that discriminant validity is fulfilled and all statements can represent problems in this research and in accordance with the actual conditions in the object of research.

\subsection{Result of reliability test}

The test result of instrument reliability is in the table below:

Based on Table 4, the reliability test result on the variables in this study indicates that all variables meet the composite reliability since the composite reliability coefficients $>0.70$ and all variables also meet internal consistency reliability since Cronbach's alpha 
TABLE 2: Composite Reliability and Cronbach's Alpha.

\begin{tabular}{|l|c|c|c|} 
No. & Variabel & $\begin{array}{c}\text { Composite } \\
\text { Reliability } \\
\text { Coefficient }\end{array}$ & $\begin{array}{c}\text { Cronbach's } \\
\text { Alpha } \\
\text { Coefficient }\end{array}$ \\
\hline 1 & PSDM & 0.902 & 0.875 \\
\hline 2 & JE & 0.869 & 0.799 \\
\hline 4 & Trust & 0.866 & 0.800 \\
\hline 5 & KP & 0.913 & 0.895 \\
\hline Source: Processed Primary Data (2018) \\
\hline
\end{tabular}

coefficients $>0.60$ so that all variables meet composite reliability and internal consistency. That is, all statements are able to measure a problem constantly. Therefore, it can be regarded as a reliable measuring tool.

\subsection{Model fit and quality indices}

The criteria shown in the goodness of fit model in Table 5 is the rule of thumb, so the results of the test should not be applied rigidly and absolutely. If there are one or two indicators of the model fit and quality indices, the model can still be used. The test results are presented in Table 5 as follows

It can be seen from Table 5 that the goodness of fit model has good result to explain the relationship between latent variables and their assumptions.

\subsection{Results of direct hypothesis testing}

Hypothesis testing was done by using resampling method and t-test. Hypothesis testing decision rule is done as follows, if the obtained p-value $\leq 0.10$ (alpha 10\%), it is said to be significant weak, if $p$-value $\leq 0.05$ (alpha $5 \%$ ) then it is said significant, and if $p$-value $\leq 0.01$ (alpha 1\%) then it is said to be significantly high in Table 6 .

\subsection{Results of mediating hypothesis testing}

\subsection{Effect of HR practices on task performance}

Based on Table 6, the result of direct effect hypothesis testing indicates that there is effect of HR practices on the task performance with the path coefficient of 0.346 and $p<0.001$. Considering that $\mathrm{p}<0.01$, then it is said to be significantly high, so $\mathrm{H}_{1}$ is 
TABLE 3: Model Fit and Quality Indices.

\begin{tabular}{|c|c|c|c|c|}
\hline No. & $\begin{array}{l}\text { Model Fit and Quality } \\
\text { Indices }\end{array}$ & Fit Criteria & $\begin{array}{l}\text { Analysis } \\
\text { Result }\end{array}$ & Description \\
\hline 1. & $\begin{array}{l}\text { Average path coefficient } \\
\text { (APC) }\end{array}$ & $P<0.05$ & $\begin{array}{c}0.442 \\
(P<0.001)\end{array}$ & Baik \\
\hline 2. & Average $R$-squared (ARS) & $p<0.05$ & $\begin{array}{c}0.411 \\
(P<0.001)\end{array}$ & Baik \\
\hline 3. & $\begin{array}{l}\text { Average adjusted } R \text {-squared } \\
\text { (AARS) }\end{array}$ & $p<0.05$ & $\begin{array}{c}0.408 \\
(P<0.001)\end{array}$ & Baik \\
\hline 4. & Average block VIF (AVIF) & $\begin{array}{l}\text { Accepted if }<=5, \\
\text { Ideally }<=3.2\end{array}$ & 1.807 & Ideal \\
\hline 5. & $\begin{array}{l}\text { Average full collinearity VIF } \\
\text { (AFVIF) }\end{array}$ & $\begin{array}{l}\text { Accepted if }<=5, \\
\text { Ideally }<=3.2\end{array}$ & 2.227 & Ideal \\
\hline 6. & Tenenhaus GoF (GoF) & $\begin{array}{l}\text { Small }>=0.1 \\
\text { medium }>=0.25 \\
\text { large }>=0.36\end{array}$ & 0.482 & Ideal \\
\hline 7. & $\begin{array}{l}\text { Sympson's paradox ratio } \\
\text { (SPR) }\end{array}$ & $\begin{array}{l}\text { Accepted if }>=0.7 \text {, } \\
\text { Ideally } 1\end{array}$ & 1.000 & Ideal \\
\hline 8. & $\begin{array}{l}R \text {-squared contribution ratio } \\
\text { (RSCR) }\end{array}$ & $\begin{array}{l}\text { Accepted if }>=0.9 \text {, } \\
\text { Ideally } 1\end{array}$ & 1.000 & Ideal \\
\hline 9. & $\begin{array}{l}\text { Statistical suppression ratio } \\
\text { (SSR) }\end{array}$ & Accepted if $>=0.7$ & 1.000 & Ideal \\
\hline 10. & $\begin{array}{l}\text { Nonlinear bivariate } \\
\text { causallity direction ratio } \\
\text { (NLBCDR) }\end{array}$ & Accepted if $>=0.7$ & 1.000 & Ideal \\
\hline
\end{tabular}

TABLE 4: The Result of Direct Effect Hypothesis Testing.

\begin{tabular}{|c|c|c|c|c|c|}
\hline No. & $\begin{array}{r}\text { Relati } \\
\text { am } \\
\text { Vari }\end{array}$ & $\begin{array}{l}\text { nship } \\
\text { ng } \\
\text { bles }\end{array}$ & $\begin{array}{c}\text { Path } \\
\text { Coefficient }\end{array}$ & P-Value & Description \\
\hline 1. & HRMP & EJ & $0.473^{\star \star}$ & $<0.001$ & Significantly High \\
\hline 2. & HRMP & Trust & $0.616 * *$ & $<0.001$ & Significantly High \\
\hline 3. & HRMP & EP & $0.346^{\star \star}$ & $<0.001$ & Significantly High \\
\hline 4. & EJ & EP & $0.415^{\star \star}$ & $<0.001$ & Significantly High \\
\hline 5. & Trust & EP & $0.411^{\star \star}$ & $<0.001$ & Significantly High \\
\hline
\end{tabular}

TABLE 5: The Result of Mediating Hypothesis Testing.

\begin{tabular}{l|l|l|l|l|l|l|}
\multicolumn{2}{r|}{ Relationship among Variables } & Path Coefficient & P-Value & Description \\
\hline X & M & Y & Path COefficient & P-Value & Description \\
\hline HRMP & JE & EP & $0.472^{\star \star *}$ & $<0.001$ & Mediating \\
\hline
\end{tabular}

supported. Path coefficient marked positive (0.346) indicates that the better practice of $H R$, then the task performance of UNNES employees will increase. 


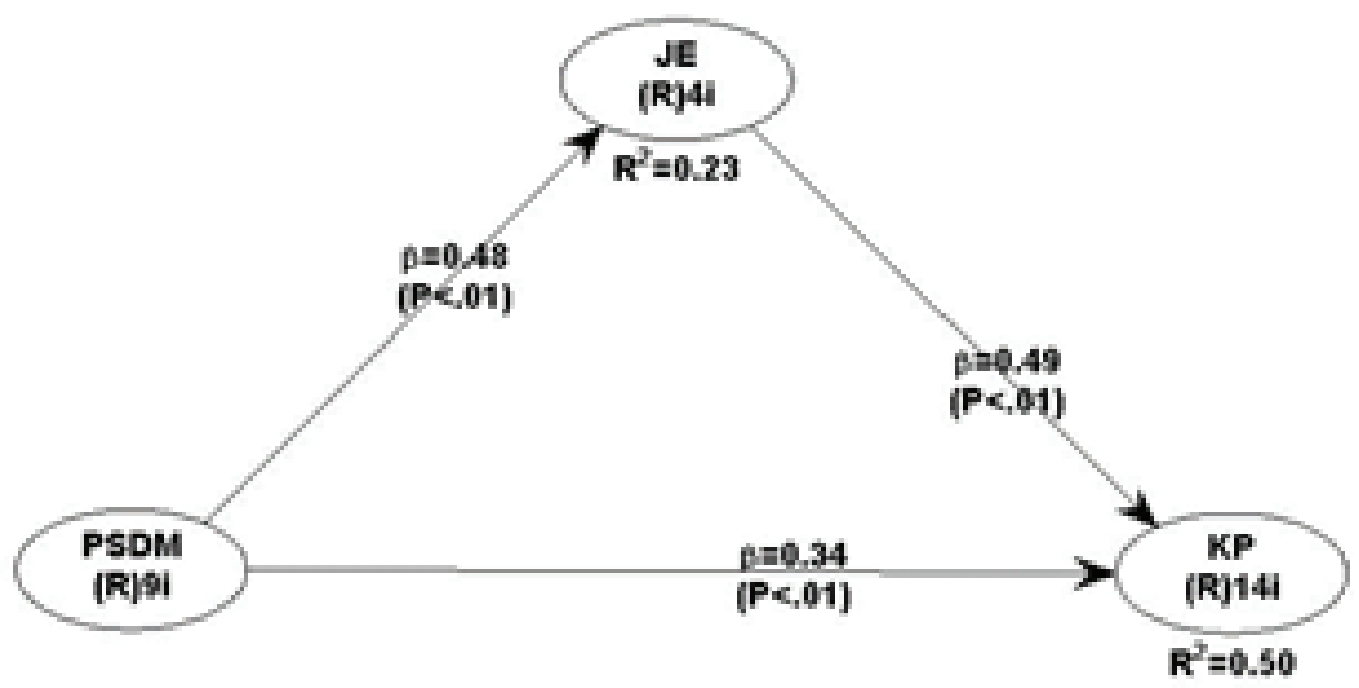

Figure 2: Testing result by involving mediating variable of job embeddedness.

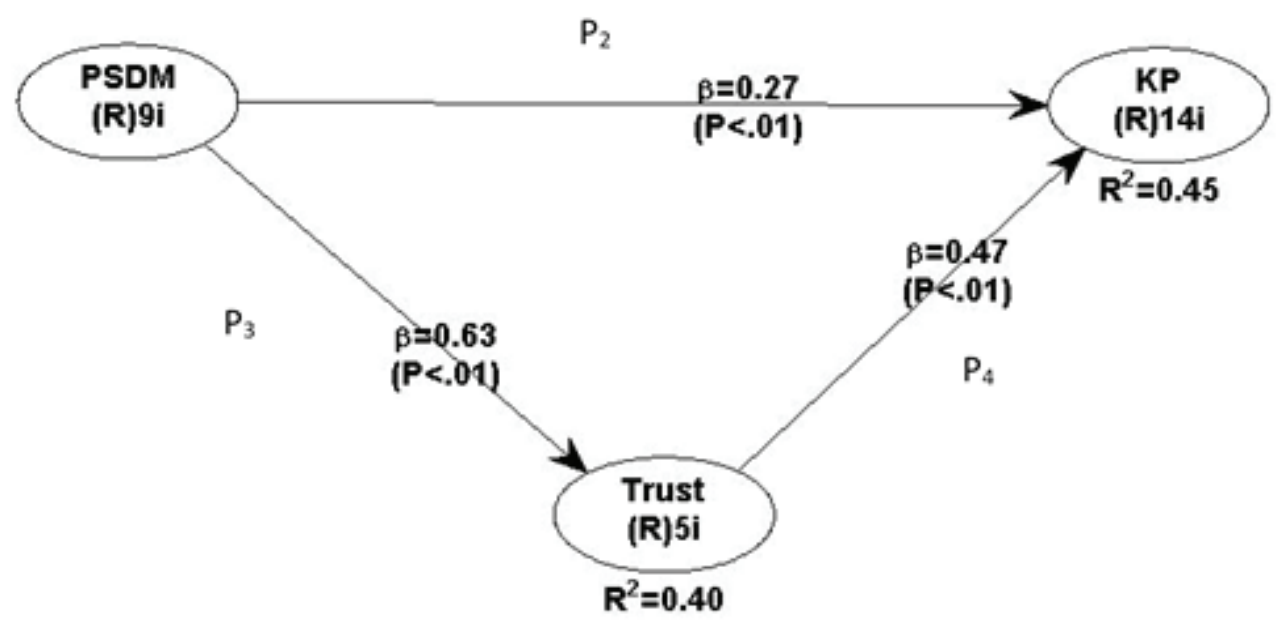

Figure 3: Testing result by involving mediating variable of trust.

The results of this study are in line with the research conducted by Kehoe and Wright (2010) which shows that HR practices contribute positively to employee performance. The study also supports Hassan (2016) demonstrating that HR practices such as Compensation, Career Planning, Performance Appraisal, Training, and Employee Involvement play an important role in improving the employee task performance. Several other studies that examine the role of HR practices on performance such as Mahadevan and Mohamed (2014), Munjuri (2011), Qudah and Qudah (2014), Sattar et al 
(2015) suggest that it is important to keep improving HR practices to improve employee performance in an organization.

\subsection{Effect of HR practices on job embeddedness}

Based on Table 6, the result of direct effect hypothesis testing indicates that there is an effect of HR practices on job embeddedness with path coefficient of 0.473 and $\mathrm{p}<0.001$. Considering that $\mathrm{p}<0.001$, then it is said to be significant, so $\mathrm{H}_{2}$ is supported. The path coefficient of 0.473 indicates that the better the HR practice in UNNES, the higher the job embeddedness of employees.

The results of this study are in line with Bambacas and Kulik (2013), Ghosh and Gurunathan (2015) indicating that good HR practices can create employee embeddedness. The better the HR practice applied by the organization, it will increase the employee job embeddedness. Therefore, it is important for universities to keep improving the HR practices in order to increase employee job embeddedness.

\subsection{Effect of HR practices on trust}

Based on Table 6 the result of direct effect hypothesis testing indicates that there is an effect of HR practice on trust with path coefficient of 0.616 and $p<0.001$. Considering that $\mathrm{p}<0.01$, it is said to be significantly high, so that $\mathrm{H}_{3}$ is supported. Path coefficient marked positive (0.616) indicates that the better the HR practice, hence the trust of employees in the organization is increasing. Research conducted by Tzafrir et al (2004), Rahman et al (2013) found that good HR practices can create employee trust in their organizations and superiors. Therefore, it is important for organizations to keep improving HR practices to create a high climate of trust.

\subsection{Effect of job embeddedness on task performance}

Based on Table 6, the result of direct effect hypothesis testing indicates that there is an effect of job embeddedness on task performance with path coefficient of 0.415 and $\mathrm{p}<0.001$. Considering that $\mathrm{p}<0.01$, it is said to be significantly high, $\mathrm{so}_{4}$ is supported. Path coefficient marked positive (0.415) indicates that the higher job embeddedness of UNNES employees, hence their task performance will increase. 
The results of this study are in line with the research conducted by Lee et al (2004), Ozcelik and Genkci (2014) indicating that employee job embeddedness will be able to drive their performance. Therefore, it is important for universities to keep paying attention to job embeddedness of their employees, in order to get a good task performance.

\subsection{Effect of trust on task performance}

Based on Table 6, the result of direct effect hypothesis testing showed that there is an effect of trust on task performance with path coefficient of 0.411 and $p<0.001$. Considering that $\mathrm{p}<0.01$, it is said to be significantly high, so $\mathrm{H}_{5}$ is supported. The path coefficient marked positive (0.411) indicates that the higher the trust of UNNES employees, the performance of their task will increase.

The results of this study are in line with the research conducted by Brown et al (2015), Akili and Cingoz (2015), Ahmed et al (2016), showing that employee trust in their organizations and superiors will be able to improve employee performance. The higher the trust of employees, the higher their performance will be. Therefore, it is important for universities to keep paying attention to the trust of their employees, in order to get good task performance.

\subsection{Effect of HR practices on task performance through job embeddedness and trust}

Based on Table 7, it is known that the indirect effect path coefficient of HR Practices on Employee Performance through Job Embeddedness and Trust is equal to 0.472 with $p$ $<0.001$. Considering that $p \leq 0.05$ it can be said to be significant, so job embeddedness and trust belong to mediating variables. Based on Figure 2, the results of the mediation analysis stated that the effect of HR practices on job embeddedness (p2) and the effect of job embeddedness on employee performance (p4) were said to be significant with p $<0.01$ and p2 path coefficient (effect of HR practices on employee performance after mediation) that is $0.34<0.56$, then job embeddedness can be said as a partial mediating variable so that $\mathrm{H} 6$ is accepted. Based on Figure 3, the results of the mediation analysis stated that the effect of HR practices on trust (p2) and the effect of trust on employee performance ( $p 4$ ) were said to be significant with a value of $p<0.01$ and path coefficient p2 (effect of HR practices on employee performance after mediation), 
which was $0.27<0.56$, then trust can be said to be a partial mediating variable, so that $\mathrm{H}_{2}$ is accepted.

The results of this study complement the previous research of Fatima et al (2015) which proposes that the effect of HR practices on employee performance in Higher Education through mediating variables such as job embeddedness and trust needs to be done in different countries and universities to produce generalized results. This study has shown that the role of HR practices in improving performance can be through mediating variables such as job embeddedness and trust. That is, the better the HR practice in higher education, the job embeddedness and employee trust will increase. Then, job embeddedness and trust will encourage good task performance.

\section{Conclusions and Implications}

Based on the results indicating that there is an effect of HR practices on task performance, the better the HR practices, the UNNES employee job performance is also increasing. HR practices also play an important role in increasing job embeddedness and employee trust in their organizations. The better the HR practices, the higher the job embeddedness and employee trust will be. Then, job embeddedness and trust can also directly improve the employee task performance. In addition to affecting directly, job embeddedness and trust also play a role as mediating variables for HR practices on performance.

The results of this study provide an understanding that good HR practices are important to apply not only to profit organizations but also to universities. Companies in general and universities in particular should keep paying attention and improve their HR practices to obtain superior performance.

This research still has limitations, as it has limited sample of employees at Semarang State University. Therefore, further research is recommended to increase the number of samples used from other universities. In addition, this study only uses a quantitative approach, so it has not been able to answer the problems that need in-depth study. Furthermore, it is recommended to use the mix method approach to obtain a deeper picture of the phenomenon. 


\section{References}

[1] Afandi, P. (2016). Concept \& Indicator Human Resources Management for Management Research. Yogyakarta: DeePublisher

[2] Afzali, A., Motahari, A., \& Shirkouhi. 2014. Investigating The Influence Of Perceived Organizational Support, Psychological Empowerment And Organizational Learning On Job Performance: An Empirical Investigation. Tehnički vjesnik 21, 3, 623-629

[3] Ahmed, W., Yasir, Nawaz, R., Imran, \& Nawaz, A. 2016. A Mediating Role of Job Security between Trust and Employees' Performance: A Case of Private Sector Hospitals of Hazara Division, Pakistan. IOSR Journal of Business and Management (IOSR-JBM). Vol 18 (9)

[4] Aktar, A. \& Pangil, F. 2017. The relathionship between employee engagement, HRM practices and perceived organizational support: evidence from banking employees. International Journal of Human Resource Studies ISSN 2162-3058

[5] Akili, S., \& Cingoz, A. 2015. The relationship between organizational trust and job performance: The mediating effect of public service motivation. Paper presented at the 2015 EGPA ANNUAL CONFERENCE, 26-28-2015, Toulouse, France

[6] Allen, D. G., Shore, L. M. and Griffeth, R. W. (2003). The role of perceived organizational support and supportive human resource practices in the turnover process. Journal of management, 29(1), 99-118.

[7] Altuntas, Serap., \& Baykal, Ulku. (2010). Relationship Between Nurses' Organizational Trust Levels and Their Organizational Citizenship Behaviors. Journal of Nursing Scholaship, Vol 42 No 2.

[8] Ardana, I Komang., dkk., 2012, Manajemen Sumber Daya Manusia, Graha Ilmu, Yogyakarta.

[9] Bambacas, M., \& Kulik, C. 2013. Job embeddedness in China: how HR practices impact turnover intentions. The International Journal of Human Resource Management, Vol. 24, No. 10, 1933-1952

[10] Baron, R. M., and Kenny, D. A. (1986). The moderator-mediator variable distinction in social psychological research: Conceptual, strategic, and statistical considerations. Journal of personality and social psychology, 51(6), 1173.

[11] Bennis, W.G. and Nanus, B. (1985). Leaders: The Strategy for Taking Charge. New York: Harper \& Row. 
[12] Bergiel, E. B., Nguyen, V. Q., Clenney, B. F. and Taylor, G. S. (2009). Human resource practices, job embeddedness and intention to quit. Management Research News, 32(3), 205-219. 5

[13] Blau, P. M. (1964). Exchange and power in social life. New York: Wiley.

[14] Brown, S., McHardy, \& Taylor K. 2015. Employee trust and workplace performance. Journal of Economic Behavior \& Organization 116 (2015) 361-378

[15] Cook, J. and Wall, T. (1980). New Work Attitude Measures of Trust, Organisational Commitment and Personal Need Non-fulfilment. Journal of Occupational Psychology, 53, 39-52.

[16] Culbert, S. A. and McDonough, J. J. (1986). The Politics of Trust and Organizational Empowerment. Public Administration Quarterly, 10: 171-88.

[17] Cunningham, G. B., Fink, J. S. and Saga, M. (2005). Extension and Further Examination of the Job Embeddedness Construct. J. Sports Manage, 19(3), 319335.

[18] De Saa-Perez, P. and JM. Garcia-Falcon. 2002. A Resource-based View of Human Resource Management and Organizational Capabilities Development. International Journal of Human Resource Management. 13. 123-40.

[19] Demerouti E., Bakker, A. B., Nachreiner, F. and Schaufeli, W. B. (2001). The Job Demands - Resources model of burnout. Journal of Applied Psychology, 86, 499512.

[20] Diffie-Couch, P. (1984). Building a Feeling of Trust in the Company. Supervisory Management, 3, 136.

[21] Emerald., T \& Genoveva. 2014. Analysis of Psychological Well-Being and Job Satisfaction toward Employees Performance in PT Aristo Satria Mandiri Bekasi, Indonesia. Proceding. Disajikan pada Kualia Lumpur International Business, Economics and Law Conferece, Kuala Lumpur, Malaysia 31 Mei - 1 Juni 2014

[22] Fatima, M., Shafique, M., Qadeer, F., dan Ahmad, R. 2015. HR Practices and Employee Performance Relationship in Higher Education: Mediating Role of Job Embeddedness, Perceived Organizational Support and Trust. Pak.j.stat.oper.res. Vol.XI No.3 2015 Pp421-439

[23] Felps, Will., Terence R. Mitchell, David R. Hekman, Thomas W. Lee, Brooks C. Holtom, Wendy S. Harman. 2009. Turnover Contagion: How Coworkers' Job Embeddedness And Job Search Behaviour Influence Quitting. Academy of Management Journal, 52(3): p: 547.

[24] Fitriyani, Windri. 2013. Pengaruh Kepribadian dan Job Embeddedness Terhadap Organizational Citizenship Behaviour (OCB) pada Karyawan PT. Hadji Kalla Makassar. Skripsi Fakultas Ekonomi \& Bisnis Universitas Hasanuddin. p: 17. 
[25] Ghosh, D., \& Gurunathan, L. 2015. Do commitment based human resource practices influence job embeddedness and intention to quit?. IIMB Management Review (2015) 27, 240-251

[26] Gould-Williams, J. (2003). The importance of HR practices and workplace trust in achieving superior performance: a study of public-sector organizations. International Journal of Human Resource Management, 14(1), 28-54.

[27] Glarino, G. G. 2013. Strategic Human Resource Management: Influences on Perceived Organizational Support and Job Attitudes. International Journal of Business and Social Science Vol. 4 No. 12

[28] Guest, D. 1997. Human Resource Management and Performance: A Review and 122 Jurnal Siasat Bisnis Vol. 15 No. 1, Januari 2011 99-123 Research Agenda. The International Journal of Human Resource Management. 8 (3). 263-76

[29] Gunawan, A., \& Azzahra, R. 2017. Kelekatan Kerja, Keterikatan Kerja, Dan Niat Untuk Pindah Kerja. Jurnal Manajemen dan Akuntansi Volume XII No.1

[30] Hassan, Saira. 2016. Impact of HRM Practices on Employee's Performance. International Journal of Academic Research in Accounting, Finance and Management Sciences Vol. 6, No.1, January 2016, pp. 15-22

[31] Hasibuan, Malayu S.P., 2009. Manajemen Sumber Daya Manusia (edisi revisi), Bumi Aksara, Jakarta.

[32] Istiqomah, M. (2015). Hubungan Gaya Kepemimpinan dengan Kepercayaan (trust) Karyawan Kepada Organisasi Perusahaan. SKRIPSI. Universitas Mercubuana Jakarta.

[33] Jouda1, A. A., Ahmad, U., Dahleez K. A. 2016. The Impact of Human Resource Management Practices on Employees Performance: The Case of Islamic University of Gaza in Palestine. International Review of Management and Marketing Vol 6 Issue 4

[34] Joosara, M., Tajasob, K., \& Ahmadian. 2015. The Relationship among Leadership style, Perceived Organizational Support, and Employees' Job Performance in Iran Khodro Dissel Company. Science Journal (CSJ), Vol. 36, No: 6 Special Issue

[35] Kehoe, R. R., \&Wright, Patrick M. 2013. The Impact of High-Performance Human Resource Practices on Employees' Attitudes and Behaviors. Journal of Management Vol. 39 No. 2, 366-391

[36] Kismono, Gugup. 2011. The Relationships Between Job Embeddedness, Work-Family Conflict, and the Impact of Gender on Turnover Intention: Evidence from the Indonesian Banking Industry. Thesis of Piloshopy: pp: 1-10. 
[37] Lee, T., Sablynski, C., Burton, J., \& Holtom. 2004. The Effects Of Job Embeddedness On Organizational Citizenship, Job Performance, Volitional Absences, And Voluntary Turnover. Academy of Management Journal. Vol. 47, No. 5, 711-722.

[38] Mitchell, Terence R., Brooks C. Holtom, Thomas W. Lee, Chris J. Sablynski, Miriam Erez. 2001. Using Job Embeddedness to Predict Voluntary Turnover. Academy of Management Journal, 44: pp:1-11

[39] Mahadevan, A., Sn Mohamed, F. A. 2014. Impact Of Human Resource Management (Hrm) Practices On Employee Performance (A Case Of Telekom Malaysia). International Journal of Accounting \& Business Management Vol. 2 (No.2)

[40] May, C. S., Xing, Kee. F. S., Ying, H., \& Mun, Ng. 2014. The Impact Of Human Resource Practices Towards Perceived Organizational Support Of Academic Staff In Utar Perak Campus. Tesis. Universiti Tunku Abdul Rahman

[41] Mayer, R. C., Davis, J. H., \& Schoorman, F. D. (1995). An integrative model of organizational trust. Academy of Management Review, 20.

[42] Moghli, Azzam A. 2015. The role of Organizational Support in Improving Employess Performance. International Business Research; Vol. 8, No. 2;

[43] Munjuri, Mercy Gacheri. 2011. The Effect of Human Resource Management Practices in Enhancing Employee Performance in Catholic Institutions of Higher Learning in Kenya. International Journal of Business Administration Vol. 2, No. 4;

[44] Nadarajaha, S., Kadiresanb, V., Kumarc R, Nissa, Kamild and Yusoff. 2012. The Relationship of HR Practices and Job Performance of Academicians towards Career Development in Malaysian Private Higher Institutions. Procedia - Social and Behavioral Sciences 57. $102-118$.

[45] Nostra, Natalia Stella. 2011. Hubungan Antara Job Embeddedness dan Organizational Citizenship Behaviour (OCB) Pada Karyawan. Skripsi Program Studi Psikologi Universitas Sanatana Dharma. p: 11.

[46] Ozcelik, G., \& Cencki, T. 2014. Moderating Effects of Job Embeddedness on the Relationship between Paternalistic Leadership and In-Role Job Performance. Procedia - Social and Behavioral Sciences 150, 872 - 880

[47] Qudah, H. M., \& Qudah, H. E. M. 2014. The Effect Of Human Resources Management Practices On Employee Performance. International Journal Of Scientific \& Technology Research Volume 3, Issue 9. Pakistan Economic and Social Review Volume 53, No. 1 
[48] Rahman, N., Alias, M. A., \& Shahid. 2013. Relationship between Islamic Human Resource Management (IHRM) practices and trust: An empirical study. Journal of Industrial Engineering and Management JIEM, 2013-6(4): 1105-1123

[49] Sattar, T., Ahmad, A., \& Hassan. 2015. Role Of Human Resource Practices In Employee Performance And Job Satisfaction With Mediating Effect Of Employee Engagement. Pakistan Economic and Social Review Volume 53, No. 1

[50] Schneider, B. and D. Bowen. 1985. Employee and Customer Perceptions of Service in Banks: Replication and Extension. Journal of Applied Psychology. 70(3). 423-433.

[51] Schneider, B. and D. Bowen. 1993. The Service Organization: Human Resources Management is Crucial. Organizational Dynamics, 21(4), 39- 52.

[52] Sohckley-Zalabak, P., Eliis, K., \& Cesaria, R. (2000). Measuring Organizational Trust. International Association of Bussiness Communicators (IABC) Research Foundation.

[53] Tzafrir, S. S., Harel, G., Baruch, Y. \& Dolan. 2004. The consequences of emerging HRM practices for employees' trust in their managers. Personnel Review Vol. 33 No. 6,

[54] Yongxing, Guo., Hongfei, Baogou, X., \& Lei. 2017. Work engagement and job performance: the moderating role of perceived organizational. anales de psicología, vol. $33,3,708-713$ 